\title{
Notarical Ethics In The Implementation Of Murabaha
}

\author{
Ebit Tri Laksono ${ }^{1}$ and Akhmad Khisni ${ }^{2}$
}

\begin{abstract}
In a business and banking transactions, there is an important thing of the existence of agreement, especially in a debt-receivable case. A Public notary as the side that has a discretionary power in making authentic agreement which has an important role in the banking transaction, not only in the Conventional Bank but also in the Islamic Bank. On of them is in the making of sharia agreement by the principal of murabaha. The agreement that was made by the public notary had the obvious strong power and could be placed as the evidence instrument, if there is a problem between two parties. The making of an authentic agreement by the public notary was required in the legislative regulations with the aim to create certainty, public order and the protection of the law.
\end{abstract}

Keywords: Public Notary; Sharia; Murabaha.

\section{Introduction}

In the explanation of Act No. 30 of 2004 concerning the Office of public notary stated that a public notary is the public officials who are authorized to create the authentic agreement of the extent to which the creation of an authentic agreement and it is not devoted to other public officials. The making of an authentic agreement required by laws and regulations in order to create certainty, public order and the protection of the law.

The authentic agreement made by or before a public notary, not only because it is required by laws and regulations, but also because the desired by the parties concerned to ensure that the rights and obligations of the parties for the sake of certainty, public order and the protection of the law for interested parties at once for the community as a whole. The notary made an authentic agreement which is the strongest authentication materials and fulfilled which have an important role in any legal relationship within each community life.

In the field of banking, the notary is one of the important elements in any banking transaction operations, especially in making the guarantee credit/financing certificates. A letter of acknowledgment of debt, gross Act, legalization and waarmerking, and other duties of the notary who has been governed by legislation. Not only at the conventional banks, but the notary is also an important element in Islamic banks, one of them in financing al-Murabaha (sale) in the practice of Islamic banking.

A notary occupies a very important position in the Islamic banking industry at present, because the notary has the authority in making the agreement, contracts binding and Islamic banking product guarantee (especially in the case of rights agreements and fiduciary). In the practice of business agreements in the banking world, certainly it needs a notary who was able to understand the concepts of Islamic marriage contract and its application in the practice of Islamic banking.

Cooperation between the notary with Islamic banks in the financing agreement contract making contains of Sharia principle, then the usual financing is handled by a public notary

\footnotetext{
${ }^{1}$ Student of Master Program (S2) of Notaries Faculty of Law UNISSULA Semarang Indonesia email: ebit.trilaksono@gmail.com

${ }^{2}$ Lecturer of Faculty of Law UNISSULA
} 
in principle contract which consists of:

- Financing the Musyarakah Financing, i.e. between 2 (two) parties to conduct a certain business, and from the business benefits will be for in accordance with the agreement;

- Mudharabah Financing, i.e. a financing where one party as Manager while the other parties as a provider of capital. While the principal repayment of financing tailored to cash flow or business client cash flow cause an effect that it will not burden the customer;

- Financing Principles of Tenancy;

- Financing of Murabaha.

In running the business, the one thing that is very important is the issue of contract (Agreement). According to experts of Islamic law said the contract is defined as the relationship between Ijab and Qabul, according to the will of religious rules that establishes the existence of influence (a result of) the object of the law in the alliance. The formulation proposed above indicating the agreement should be an agreement both parties for committing each side about the acts that will be done in a special thing. This contract is manifested, first, in Ijab and Qabul. Second, is in accordance with the Sharia. Third, the existence of legal consequences of the object of the alliance. ${ }^{3}$

The agreement (the contract) as one way to acquire property in Islamic law, and it is a way that is widely used everyday. The contract is the way that Allah S.W. T approves and should be enforced contents. ${ }^{4}$

The contract comes from the Arabic al-aqd that etymologically means the alliance, the agreement and conspiracy (al-ittifaq). In the language means al-ikhtilat (mixture) and fellowship. According to scholars, the evidence of a marriage is between two people of Assembly on staple property (capital) and to gamble. ${ }^{5}$

Covenant of plural al-' uqud according to language means al-rabtb. Al-rabtb which means the bond or binding. ${ }^{6}$ According to Mustafa al-Zarqa in his book al-Madhkal al-'Amm al Fiqh, that is al-rabtb, namely: "Gathering or collecting the two ends of the string and tying one on the other until both are melted away and become like a piece of string that one ". 7 Understanding legal terminologically from Fiqh, in contract, is an agreement between the ijab (Overture) and Qabul (acceptance) by authorized sharia (Islamic law), which sets the means (compliance) both sides. So it can be said that the notion of contract is not just a contract between two parties to the transaction, but there is a relation to the provisions of Islamic law. ${ }^{8}$

The notion of contract, according to article 1 of the number 13 Act No. 21 of 2008 about Islamic banking mentioned that: "the contract is a written agreement between the bank or

\footnotetext{
3 Faturrahman Djamil 2001 Hukum Perjanjian Syariah Dalam Kompilasi Hukum Perikatan Oleh Mariam Darus Baddrulzaman et.al. First publition Citra Aditya Bakti Bandung pp. 247. ${ }^{4}$ Abdullah Kelib 29 Juni 2010 Peran Serta Hukum Dalam Sistem Ekonomi Syariah Training of Notary on Islamic Banking Held by Indonesian Notary Asosiation Semarang pp. 13.

${ }^{5}$ Abdul Rahman Ghazaly Ghufron Ihsan dan Sapiudin Shidiq 2012 Fiqh Muamalat Second publition Kencana Prenada Media Group Jakarta pp. 50.

${ }^{6}$ Abd. Bin Nuh dan Oemar Bakry 1964 Kamus Arab Indonesia Inggris Third Publition Mutiara Jakarta pp. 112.

${ }^{7}$ Ghufron A. Mas'adi 2002 Fiqh Muamalah Kontekstual First publition Raja Grafindo Persada Jakarta pp. 75.

${ }^{8}$ Abdullah Kelib loc.cit.
} 
Sharia business units (UUS) and the other party containing the existence of rights and obligations for each party according to the principles of Islam".

As mentioned in a cooperation with Islamic banking, it was notarized in agreement of Covenant-making transactions in murabaha. Murabaha is one form of sale and the nature of the mandate. Murabaha concluded between buyer and seller based on the price of the original purchase price of the goods, the seller is known by the buyer and to the seller any chance notified to the buyer. ${ }^{9}$

Any form of transactions on Shariah contract needs Islamic banks, including murabaha transactions. The contract requires the services of a murabaha, as well as in the manufacture of appointment in the form of an authentic Agreement.

From the explanation above, the authors formulate the problem: how is the notarical ethics in the implementation murabaha?

\section{DISCUSSION}

In article 1 paragraph (3) of the Constitution of the Republic of Indonesia 1945 establish that: " Indonesia is a state of law". Indonesia as a State of law, then both in the organization and in the life of a nation should not deviate from the law/Act.

According to Jimly Asshiddiqie, he stated that the concept of the law serves as a means to realize and reach the destination of countries of Indonesia, namely to protect all the people of Indonesia, promote the general welfare, the intellectual life of the nation and participate in implementing the world peace order based on freedom, lasting peace and social justice. ${ }^{10}$

The Constitution of the Republic of Indonesia 1945 that is in a core of truth and justice, ensuring certainty, public order and the protection of the law in the Republic of Indonesia. One of them is in the interest of certainty, in ensuring public order and the protection of the law about the circumstances, events, or the agreements of the law is evidenced by the existence of authentic written evidence tools that are implemented through a specific position, by the notary as a public official. The notary plays a role in the making of the contract, and is authorized to certify the signatures, saving agreement, giving gross, a copy of the certificate and obtain quotations and letters under the hand.

Sudikno Mertokusumo gives aa definition of notary as a public official has the authority to make an authentic agreement concerning all agreements, agreements and assignments ordered by general regulation rule or requested by the party who made the agreement. ${ }^{11}$

A public notary is already known by the public widely, and the presence of a public notary is necessary in the making of the agreement as a tool of the authentic written evidence of an act of law carried out by the community. The authentic agreement made by a notary that has the power of a strong legal and authentic agreement is the perfect instrument of evidence, so as statutory regulation rules require specific legal agreements made in the form of an authentic agreement, as in the establishment of a limited liability company,

\footnotetext{
${ }^{9}$ Hasballah Thaib 2005 Hukum Aqad (Kontrak) Dalam Fiqih Islam Dan Praktek Di Bank Sistem Syariah Doctoral Program of USU Medan pp. 121.

10 Jimly Asshiddiqie 2009 Menuju Negara Hukum yang Demokratis Bhuana Ilmu Populer Jakarta pp. 205.

${ }^{11}$ Laurensius Arliman S. 2015 Notaris dan Penegakan Hukum Oleh Hakim Jogjakarta pp. 3.
} 
coop, fiduciary guarantee agreement, the sale of land, and so on.

A notary is a public official/State officials appointed by the State to perform the duties of the State in legal services to the community in order to achieve legal certainty as the authentic agreement official in matters of civil law.

A public notary is a public officer who is authorized to make an authentic agreement and other authorities, as referred to in Act No. 30 of 2004 concerning the Office of public notary that has been changed by Act No. 2 of the of of 2014 junto the Act No. 30 of 2004 concerning the Office of public notary. Article 1 point 1 of the Act No. 2 of the of 2014 mentions that: "Public notary officer is authorized to make an authentic agreement and has other authorities that referred to in this Act or any other Act".

A notary is a legal profession whom a noble profession (nobile officium). Referred to as the nobile officium due to the profession of public notary is very closely related to humanity. The agreement that were made by a notary could be pedestal top legal status of property, rights and obligations of a person. The confusion over the notary agreement might cause the loss of the right person or carry a burden by a person of an obligation. ${ }^{12}$

Duties of a public notary is organizing the legal relationship between the parties in written form and specific format, so it is an authentic agreement. He is the maker of the powerful document in a legal process. ${ }^{13}$

G.H.S. Lumban Tobing explained that the notary agreement can be differentiate into two kinds, namely: ${ }^{14}$

- Agreement made by a notary (door) in practice called agreement of news event that contains a description of what is seen and witnessed by a notary himself at the request of the parties to then poured in the notary agreement;

- Agreement created before (tend overstaan) which in the practice, is also known as Act party (partij acte) containing descriptions or explanation, a statement the parties granted or told before a notary. The parties ordered the captions and descriptions in the form of a notary agreement.

Public notary of his existence is indispensable in transactions in banking, including in Islamic bank and especially in the making of Covenant agreement of financing in Islamic banks, because in terms of financing are always posting need a contract containing a clause to download the complete guarantee legal certainty by the order to minimize the risks borne by the Islamic banks in the transaction of financing.

Murabaha financing, as one of the products from the Islamic bank is one form of sale in Islam, in the form of transaction stuff with the addition advantage that has been agreed on.

In the execution of the agreement of Covenant of murabaha, banks sell goods to customers by means of on-credit, although his main principle of murabaha can also be done by cash. Due to the practice of the bank installment requires the existence of a guarantee by the debtor for the payment or repayment of back on the debt that had been

\footnotetext{
${ }^{12}$ Abdul Ghofur Anshori 2009 Lembaga Kenotariatan Indonesia Perspektif Hukum dan Etika UII Press Yogyakarta pp. 7.

${ }^{13}$ Tan Thong Kie 2000 Studi Notariat Serba-serbi Praktek Notaris First Edition Van Hoeve Jakarta pp. 159.

${ }^{14}$ G.H.S. Lumban Tobing 1983 Peraturan Jabatan Notaris Erlangga Jakarta pp. 51 and 52.
} 
Volume 5 Issue 2, June 2018

rendered. The Bank asks the customer to the debtor to surrender the collateral.

A good warranty is an alliance among the creditors with the debtor, where the debtor give an agreement a number of assets to repay the debt, according to the applicable statutory provisions, if within the specified time occurs congestion the payment of the debt the debtor. ${ }^{15}$

Guaranty is permissible in Islam because based on the hadeeth of Abu Dawood and Tarmizi, the Prophet said that its meaning, namely: "that debt must be paid fully and the guarantee must also pay for it". In the history of Prophet ever guarantee armor himself to a Jew in Medina, during the debt of wheat for the needs of his household, it is told by his friend, Anas and then it is stated by Ahmad, Bukhari, Nasa'i and Ibn Maajah. ${ }^{16}$

In Islamic banking transactions which require legal certainty for the parties, especially in terms of debt-receivable, then in accordance with those powers in making the agreement, the notary is entitled to make all the necessary agreement by the parties throughout the authority to make such a agreement is not excluded to the other party.

As a debt-receivable, in this murabaha financing agreement, it required a notary agreement of the authentication in the making. Notarial agreement of sale-purchase agreements will create a murabaha. In addition, the bank has a role that is as a creditor and the debtor as a borrower, customer may request the advice of the law to the public notary on the binding or the Covenant that they will create and will be organized in the notary agreement, either before, during, or after the agreement of the notary is signed.

Islamic banks will conduct a consultation or a request for some advices of the law on notary regarding guarantees which is given by the candidates in the petition for the debtor financing raised on the part of banks, for example regarding the validity of the letters filed candidates of the debtor, although not closed to the possibility to ask for advices at the public notary on matters or other problems faced by the banks, especially associated with the law.

With the presence of an authentic agreement means having the power of strong confirmation, moreover a agreement that contains the agreement that binds both parties that made the Covenant. Therefore, between the parties made an agreement that dispute, then what is the authentic agreement that is perfect proof, so it did not need to be proven again with other authentication tools. Therein lies the significance of the authentic agreement in the everyday practice of law facilitates the confirmation and provide a stronger legal certainty, so that here the notary had a position and a very important role related to the agreement law in the making of the treaty or alliance, in this case included in the field of civil law in general. Notary services are badly needed, particularly its role in the making of the agreement or contract for coordinating the interests of the community as the parties that need the services of a notary.

As mentioned by Liliana Tedjosaputro that the notary is the only public officials who are given an authority by the state to create an authentic agreement. The making of an authentic agreement conditioned based legislation to create legal certainty, public order

\footnotetext{
${ }^{15}$ Gatot Supramono 1995 Perbankan dan Masalah Kredit Yuridical Review Jakarta Djambatan pp. 56.

${ }^{16}$ Sulaiman Rasyid 2003 Fiqih Islam Sinar Baru Agensindo Jakarta pp. 309-313.
} 
and the protection of the public. ${ }^{17}$

R. Subekti suggests that authentic agreement is a proof that binding, it has the sense that what is written on the certificate must be trusted by the judge, that is to be considered true, during the untruth cannot be proven. ${ }^{18}$

In addition to making an authentic agreement, notary authority expanded after discharge of Act No. 30 of 2004 concerning the Office of a notary, so that in addition to making an authentic agreement, in article 15 paragraph (2) of Act No. 30 of 2004 about the Office Notary, public notary authorities also:

- To endorse the signature and set the certainty of the date of the hand with the register in a special book;

- To obtain letters under the hand with the register in a special book;

- To make copies of the original letters in the form of a copy containing the description as written and portrayed in the letters in question;

- To do the endorsement letter with a photocopy of the original match;

- To provide legal counselling in connection with the making of the Act;

- To create a certificate relating to land;

- To make a treatise agreement auction.

While according to notary Komar Andasasmita that in addition to the authentic agreement made, he also does: ${ }^{19}$

- To act as legal counsel, especially regarding the issue of civil law;

- To register the agreement-a agreement/letters below the hands (stukken), melaku-kan waarmerking;

- To approve a signature;

- To create and certify (waarmeken) copies/derivatives of various documents;

- To initiate the legalization of the agencies, such as the limited liability company and the Assembly, in order to gain approval/endorsement as a legal entity of the Ministry of Justice;

- To make the description of inheritance (under hands);

- To other works that related to the field of taxation and juridical, Customs Affairs such as postage labels and so on.

The importance of the role of the public notary in facilitating to create legal certainty and the protection of the law for the community more preventive in nature, namely the prevention of the occurrence of legal problems, by the way of issue-right authentic Act made before him that related to the legal status, rights, and obligations of a person in the law that serves as the most perfect instrument of evidence in the court in the event of a dispute over rights and the obligations associated with it. ${ }^{20}$

\footnotetext{
17 Liliana Tedjosaputro 1995 Etika Profesi Notaris Dalam Penegakan Hukum Pidana Bayu Grafika Yogyakarta pp. 166.

${ }^{18}$ R. Subekti 1991 Hukum Pembuktian Pradya Paramita Jakarta pp. 48.

${ }^{19}$ Komar Andasasmita 1983 Notaris Selayang Pandang Bandung Alumni pp. 7.

${ }^{20}$ Sjaifurrachman dan Habib Adjie 2001 Aspek Pertanggungjawaban Notaris Dalam Pembuatan Akta Mandar Maju Bandung pp. 7.
} 
Volume 5 Issue 2, June 2018

\section{CLOSING}

\subsection{Conclution}

A public notary is one of the important elements in any banking transaction operations, especially in making the guarantee of credit/financing certificate, and other duties of the notary who has governed by the legislation. A notary occupies a very important position in the Islamic banking industry at present, because the notary has the authority in making the agreement binding contract and the Islamic banking product guarantee (especially in the case of rights agreements and fiduciary).

Any form of transactions on the Shariah contract needs Islamic banks, including murabaha transactions. The contract requires the services of a murabaha Sharia notary, as well as in the making of the agreement in the form of an authentic Act. In addition, the bank as creditor and debtor as borrower, and customer may request the advice of the law on public notary on the binding or Covenant that they will create and will be organized in the notary agreement, either before, during, or after the agreement of the notary is signed. Islamic banks can also do consulting or legal advice on ask the notary concerning the guarantees given by the candidates in the petition for the debtor financing raised on the part of the bank.

\subsection{Suggestion}

In the practice of the treaty business in Islamic banking now, certainly, it is in a dire need of a notary who was able to understand the concepts of Islamic marriage contract and its application in the practice of Islamic banking, so it is necessary to organize education specific to the notary.

\section{References}

[1] Abd. Bin Nuh dan Oemar Bakry 1964 Kamus Arab Indonesia Inggris Third Publition Mutiara Jakarta.

[2] Abdul Ghofur Anshori 2009 Lembaga Kenotariatan Indonesia Perspektif Hukum dan Etika UII Press Yogyakarta.

[3] Abdul Rahman Ghazaly Ghufron Ihsan dan Sapiudin Shidiq 2012 Fiqh Muamalat Second publition Kencana Prenada Media Group Jakarta.

[4] Abdullah Kelib 29 Juni 2010 Peran Serta Hukum Dalam Sistem Ekonomi Syariah Training of Notary on Islamic Banking Held by Indonesian Notary Asosiation Semarang.

[5] Faturrahman Djamil 2001 Hukum Perjanjian Syariah Dalam Kompilasi Hukum Perikatan Oleh Mariam Darus Baddrulzaman et.al. First publition Citra Aditya Bakti Bandung.

[6] G.H.S. Lumban Tobing 1983 Peraturan Jabatan Notaris Erlangga Jakarta.

[7] Gatot Supramono 1995 Perbankan dan Masalah Kredit Yuridical Review Jakarta Djambatan.

[8] Ghufron A. Mas'adi 2002 Fiqh Muamalah Kontekstual First publition Raja Grafindo Persada Jakarta.

[9] Hasballah Thaib 2005 Hukum Aqad (Kontrak) Dalam Fiqih Islam Dan Praktek Di 
Bank Sistem Syariah Doctoral Program of USU Medan.

[10] Jimly Asshiddiqie 2009 Menuju Negara Hukum yang Demokratis Bhuana Ilmu Populer Jakarta.

[11] Komar Andasasmita 1983 Notaris Selayang Pandang Alumni Bandung.

[12] Laurensius Arliman S. 2015 Notaris dan Penegakan Hukum Oleh Hakim Jogjakarta.

[13] Liliana Tedjosaputro 1995 Etika Profesi Notaris Dalam Penegakan Hukum Pidana Bayu Grafika Yogyakarta.

[14]R. Subekti 1991 Hukum Pembuktian Pradya Paramita Jakarta.

[15] Sjaifurrachman dan Habib Adjie 2001 Aspek Pertanggungjawaban Notaris Dalam Pembuatan Akta Mandar Maju Bandung.

[16] Sulaiman Rasyid 2003 Fiqih Islam Sinar Baru Agensindo Jakarta.

[17] Tan Thong Kie 2000 Studi Notariat Serba-serbi Praktek Notaris First Edition Van Hoeve Jakarta. 